\title{
Determinants of Sovereign Ratings in Emerging Countries with Panel Probit Analysis
}

\author{
Dayioglu Tugba \\ Department of Management and İnformation System, Economy Faculty, Nisantasi University, İstanbul, Turkey
}

\section{Email address:}

tugba.dayioglu@nisantasi.edu.tr

\section{To cite this article:}

Dayioglu Tugba. Determinants of Sovereign Ratıngs in Emerging Countries with Panel Probit Analysis. International Journal of Engineering Management. Vol. 3, No. 1, 2019, pp. 6-11. doi: 10.11648/j.ijem.20190301.12

Received: June 8, 2019; Accepted: July 3, 2019; Published: July 17, 2019

\begin{abstract}
The aim of this paper is to study determinants of sovereign ratings of emerging countries. The ratings are analyzed with panel ordered probit model. The economic indicators are used and these variables of the countries are independent for the sovereign ratings. In this study we determined the effective factors on ratings and we check the effects of current account deficits, external debts, gross domestic product per capita, real exchange rates, inflations, unemployement and political qualities on sovereign ratings that are exported by three large rating agencies (S\&P, Moodys and Fitch). This paper studies sovereign rating models of Moody's, Standard \& Poor's (S\&P) and Fitch to identify important determinants of sovereign ratings. The credit agencies are taking attention some economic and political indicators of the countries on their credit limits. Sovereign credit ratings plays an imperative role in the decision-making process of where and when to invest and determine the interest that is paid to investors for sovereign debt borrowings. This sovereign credit scoring probability is estimated with panel ordered probit model in our study.
\end{abstract}

Keywords: Sovereign Rating, Credit Rating Agencies, Panel Probit Models

\section{Introduction}

The creditworthiness is determined by credit rating agencies which are assessing the country's risk of default by evaluating a broad range of elements. Credit rating agencies such as Moody's, S\&P's and Fitch have an important position when issuing these ratings.

They indirectly control the country's access to the international capital markets but also due to the ceiling that is set for domestic entities associated with the country as well as the effect they have on investment decisions [1].

In the recent studies the determinants of the credit ratings are shown with many fundamental variables such as per capita income, GDP, growth, inflation, external dept all significantly affects the rating agencies evaluations (such as: $[1,2,6,19])$. These fundamental variables can explain the probability of the sovereign rates.

The rating agencies use a combination of several quantitative and qualitative variables (economic, social and political) in order to assign a credit rating to a debtor or to a debt instrument [17] explained in their study. As a consequence, an important issue is to identify the various factors which are statistically significant in the determination sovereign credit ratings.

Sovereign credit ratings plays an imperative role in the decision making process of where and when to invest and determine the interest that is paid to investors to improve the effectiveness of investment decision for bonds and other fixed income instruments [21].

This paper used the one of the way models to find the sovereign credit probabilities. In such studies for this scoring scales using dummies but in this study to show the all scales probability we used the panel ordered probit model. Using panel dataset for 17 emerging countries that another some of the vaiables couldnt find equally in the years so we dindt take the some of the emerging countries. The econometric results indicate that sovereign rates are effected the such macroeconomic fundementals. In some litearute this issue based on fixed effect model with robust standart errors. Global fiancial conditions play a central role determining the variability of spreaads. Stronger GDP growth helps the reduce borrowing costs while higher international rereserves lead to lower spreads only in the case of speculative grade countries in such studies are explanied. 
The rest of paper is organized as follows first the literarure about the sovereign ratings and determinants of spreads. Sovereign credit rates and data for the emerging countries and panel probit model is explained. Finally we estimated the panel probit models for all scoring probabilities for the emerging countries and we take the three big credit scoring agenciesThe last summarizes and conclusion remarks.

In the study we used the ordered response models. These methods should determine themselves the size of differences between each category. Ordered probit model had been used in the study [13].

\section{Literature Review}

In recent time an extensive list of publications has treated the subject of credit rating determinants and creditworthiness. In an early paper Cantor and Packer [6] tested the relative significance of eight variables which have been frequently cited by S\&P's and Moody's to be used in their ratings of sovereigns.

In their study they used a multiple regression OLS framework where Moody's and S\&P's difference in credit ratings served as the dependent variable. The explanatory variables per capita GDP, GDP growth, inflation, external debt ratio, economic development and default history all rendered significant results. Although the methodology has varied, the same variables have been determining the credit ratings in numerous recent studies (such as: $[1,2,20]$ ).

Two main strands of econometric approaches exist in the literature of credit ratings [2]. The first one applies linear regression methods on a numerical representation of credit ratings (such as: $[1,4,6]$ ). Using OLS analysis on a numerical representation of the credit ratings also allows for a straightforward generalization to panel data by fixed or random effects estimation ([8, 19]). The second strand uses ordered response models. Credit ratings being of qualitative ordinal nature, the established wisdom argue for the use of ordered probit/logit estimation, this methodology has been used by several studies in recent time (such as: $[5,13,17]$ ).

In the study [2] included both strands in their methodology and employed panel estimation and a random effects ordered probit specification to evaluate several macroeconomic and public governance variables. Pretorius and Botha (2014) determined their sovereign rates with the pooled model, random effect and fixed effect probit models in their study using credit ratings on Africa. The relationship between credit spreads and credit ratings is intuitive through the idea of creditworthiness [7]. In the study [6] also aprove this relationship in their earlier mentioned article. They find evidence that the rating agencies opinions independently affect credit spreads and that the evaluated macroeconomic variables are effectively engulfed by the credit ratings and therefore strongly correlated with the market determined credit spreads. In the some literature sovereign debt is commonly used to denote debt issued by national governments and certain fiscally autonomous territories - is a contractual obligation. Government responses to financial distress can take many forms. A default has effectively occurred because actions by the sovereign result in economic losses by creditors, which can vary widely.

The study [19] are used the pooled ordinary least square regressions and feasible generalized least squares panel data regression. They focused on the emerging market economies. They found the GDP has the most significant impact on rating changes across countries.

Credit rating from the major agencies are ued the panel ordered probit model to estimate the parameters of relevant determinants of sovereign rating. Sovereign credit ratings are inversely proportional to the default probability. The main economic variables usually are onsidered in the literature are: per capita income, gross domestic product (GDP) growth, inflation rate, economically development, ratios of foreign debt to GDP, real exchange rate, and default history.

In this study we explained sovereign ratings probability for all levels given to emerging countries.

\section{Sovereign Credit Ratings and Data}

In this study we explained sovereign ratings of emerging countries such as Brazil, Hungary, Mexico, India, Malaysia, Russia, Poland, South Africa, Thailand, Egypt, Indonesia, Check Republic, Philippines and Turkey, Peru. Total of these countries were used in this study using ratings by S\&P, Moody's and Fitch. The ratings in this study were converted ratings scales with panel probit models. The credit agencies notes are different but we obtained the levels as probit scales.

The selected sovereign credit rates from credit rating agencies such as Fitch or S\&P website. Explonatory variables are obtained from the World Bank, IMF, Federal Bank Reserve, Counrty economy websites and Heritage Foundation.

The variables data are obtained between 2000 and 2017on an annual basis such as sovereign ratings of S\&P, Moodys and Fitch credit agencies ratings in the NKC own comparative ratings (NCK, 2016). The top rating is 'AAA' and the bottom ' $\mathrm{D}$ ' (the lower the raitng the bigger the probability of defult. These rating agencies even use the some symbols $(+,-)$ to differetiate between sovereign states in the same category.

In this study we used the countries variables which are effective on sovereign ratings these explanotary variables in our study are GDP per capita (GDPP), Inflation (INF), Unemployement (UNE), GDP Growth (GDPG), External Dept (GD), Real Exchange Rates (REXC), Current Account Deficit (CAD).

The variables are observed between 2000 and 2017 on an annual basis. Data for the series GDP growth, GDP per capita and inflation was obtained from Federal Reserve Economic Data, Economy Data web site. GDP per capita is measured in constant prices with logarithms of thousand U.S. dollars as unit. Inflation is obtained from World Bank. Inflation is measured as the percentage change of the yearly averages of the consumer price index. External debt is measured as one hundredth of the quote between external debt and exports. The External dept was obtained from Historical Public Dept 


\section{Database.}

Data for the external debt variable was obtained from the World Bank (GDF). GDP growth is measured in constant prices with percentage change as unit. External debt is measured as one hundredth of the quote between external debt and exports. Real exchange rate (REXC) calculated against US dollars. The explanatory variables are presented in Table 1 belowed,

Table 1. Description of Explanatory Variables.

\begin{tabular}{|c|c|c|}
\hline Explanatory Variables & Unit & Notes \\
\hline GDP per capita (GDPP) & USA Dollars & Constant prices \\
\hline Inflation (IN) & Percantage change & $\begin{array}{l}\text { Annual averages of } \\
\text { consumer price inflation }\end{array}$ \\
\hline $\begin{array}{l}\text { CurrentAccountBalance } \\
\text { (CAB) }\end{array}$ & $\begin{array}{l}\text { Annual rela growth on } \\
\text { a year on year basis }\end{array}$ & Constant prices \\
\hline GDP Growth(CDPG) & Percantage change & \\
\hline Unemployement(UN) & $\begin{array}{l}\text { External dept to DPD } \\
\text { Percantage change }\end{array}$ & Totat dept services \\
\hline Exchange Rate (ER) & US dollar & \\
\hline External Dept (GD) & Externaldept/export & \\
\hline
\end{tabular}

The sovereign rates of the credit agencies are taken from World bank sovereign rates data. Three majör credit agencies indicate that their assesments of goverment risk are based on the analysis of broad set of economic, social and politic factors [10]. The rates are shown in Table 2 belowed. Rating and their explanations are summarized in Table 1.

Table 2 countries with a rating of BBB-or above in the case of S\&P and Fitch, and Baa3 or above in the case Moody's, are considered to be in the inverstment grade asset class; countries with ratings below that threshold are considered to be in the speculative grade asset class.

Table 2. Rating Symbols.

\begin{tabular}{|c|c|c|c|c|}
\hline \multirow{2}{*}{$\begin{array}{l}\text { Specifications } \\
\text { Investment grade rating } \\
\text { Highest quality }\end{array}$} & \multicolumn{3}{|c|}{ Symbols } & \multirow{2}{*}{$\begin{array}{l}\begin{array}{l}\text { Ordered } \\
\text { probit scale }\end{array} \\
6\end{array}$} \\
\hline & AAA & AAA & Aaa & \\
\hline \multirow[t]{3}{*}{ High quality } & $\mathrm{AA}+$ & $\mathrm{AA}+$ & Aal & 5 \\
\hline & AA & $\mathrm{AA}$ & $\mathrm{Aa} 2$ & 5 \\
\hline & $\mathrm{AA}^{-}$ & $\mathrm{AA}^{-}$ & $\mathrm{Aa} 3$ & 5 \\
\hline \multirow[t]{3}{*}{ Strong payment capacity } & $\mathrm{A}+$ & $\mathrm{A}+$ & $\mathrm{A} 1$ & 4 \\
\hline & A & A & $\mathrm{A} 2$ & 4 \\
\hline & $\mathrm{A}^{-}$ & $\mathrm{A}^{-}$ & $\mathrm{A} 3$ & 4 \\
\hline \multirow[t]{3}{*}{ Adequate payment capacity } & $\mathrm{BBB}+$ & $\mathrm{BBB}+$ & Baal & 3 \\
\hline & $\mathrm{BBB}$ & BBB & $\mathrm{Baa} 2$ & 3 \\
\hline & $\mathrm{BBB}-$ & $\mathrm{BBB}-$ & Baa3 & 3 \\
\hline \multirow[t]{3}{*}{$\begin{array}{l}\text { Speculative-grade ratings } \\
\text { Likely to fulfill obligation }\end{array}$} & $\mathrm{BB}+$ & $\mathrm{BB}+$ & Ba1 & 2 \\
\hline & BB & $\mathrm{BB}$ & $\mathrm{Ba} 2$ & 2 \\
\hline & $\mathrm{BB}-$ & $\mathrm{BB}-$ & $\mathrm{Ba} 3$ & 2 \\
\hline \multirow[t]{3}{*}{ High-risk obligation } & $\mathrm{B}+$ & $\mathrm{B}+$ & B1 & 1 \\
\hline & $\mathrm{B}$ & B & B2 & 1 \\
\hline & B- & B- & B3 & 1 \\
\hline \multirow[t]{6}{*}{ Obligations cannot meet } & $\mathrm{CCC}+$ & $\mathrm{CCC}+$ & Caal & 0 \\
\hline & $\mathrm{CCC}$ & $\mathrm{CCC}$ & $\mathrm{Caa} 2$ & 0 \\
\hline & $\mathrm{CCC}^{-}$ & $\mathrm{CCC}^{-}$ & $\mathrm{Caa} 3$ & 0 \\
\hline & $\mathrm{CC}$ & $\mathrm{CC}$ & $\mathrm{Ca}$ & 0 \\
\hline & $\mathrm{C}$ & $\mathrm{C}$ & $\mathrm{C}$ & 0 \\
\hline & SD & SD & D & 0 \\
\hline
\end{tabular}

Source: Cantor and Packer [6]
The regression between sovereign rating and explanatory variables are stated in Equation 1.

$N=1, \ldots 7: t=2000, \ldots, 2017$ and the model is,

$$
Y_{i t}^{*}=\beta x_{i t}+u_{t}
$$

Where the yit represents the sovereign credit rating of country $i$ in period $t$, xit is a vector of explanatory variables and $\beta$ is a unknown parameter vector. The dependant variable

Yit represents sovereign ratings and we estimated the models were used including S\&P, Moody (MDY), Fitch (FTC) ratings.

\section{Econometric Framework and Empiricial Results}

In this study is to determine the sovereign credit ratings and the ratings fundemantals of the emerging market countries using the panel probit model as the estimation of the credit scoring levels probability with determined ordered scales.

Sovereign credit rating will be taken panel probit model will be used for the panel of selected emerging market countries. The panel probit models are suggested to prevent the linear porbability models problems that we have met. The panel probit model is specified,

$$
F\left(\beta x_{i t}\right)=Q\left(\beta^{\prime} x_{i t}\right)=\int_{-}^{\beta x_{i t}} \frac{1}{\sqrt{2 \pi}} e^{-\frac{-u^{2}}{2}} d u
$$

The panel probit model has standart normal cumulative distribution function. The panel probit and panel logit models could be estimated with maksimum likelihood method. In the panel probit model if the model has unknown heterogenacity,

$$
\pi\left(\mu_{i} x_{i t}\right)=\varnothing\left(\pi\left(\mu_{i}+\beta x_{i t}\right)\right.
$$

The $\mu \mathrm{i}$ shows unit effect than could be done created as the random and fixed effect. In the panel probit model the significance of the coefficient are done with $\mathrm{Z}$ test. The all the parameters significance are searched with a test which smiliar to $\mathrm{F}$ test but using chi-square distribution. After model estimation the marjinal effects can be calculated for the Panel probit models [1].

$Y_{t}$ is a variable represents the sovreign credit rating of counrty $\mathrm{i}$ in period $\mathrm{t}$. Xt is the explonatory variables vector and $\mathrm{B}$ parameter represents the unknown parameter vector. The sovereign credit rating in the following way,

$$
y_{i<\tau_{1}}^{*} \mathrm{y} \text { is equal to } 1
$$

As follows such

$$
\begin{aligned}
& \tau_{1}<y_{i}^{*}<\tau_{2} y_{i} \text { is equal to } 2 \\
& \tau_{2}<y_{i}^{*}<\tau_{3} \text { yi is equal to } 3 \\
& \tau_{3}<y_{i}^{*}<\tau_{4} \text { yi is equal to } 4
\end{aligned}
$$

And continued like that using these threshold or cutpoints. 
They are parameters and are estimated like this [14].

When the models have large cross section $(\mathrm{N})$ and time periods $(\mathrm{T})$ there would be difference between the random effect and fixed effect models. For this reason the random effects model should produce more efficient estimators than fixed effects [5].

Even $\mathrm{T}$ is large and $\mathrm{N}$ small there is little difference between the random and fixed effects and the fixed effects are preferred on computational convenience [3].

Sovereign ratings are adequated such as the payment capacity obligation can not be met, high or risk obligation, fullfill obligation, strong payment capacity, high payment capacity and highest payment capacity. In the application the dependant variables take quantiative and countable values that they are shown with ordinary scale structure. If the qualitative dependant variables have two choicec they called binary choice models like binary logit models. If the qualitative dependant variables (such as: $[4,6,9,18])$. The sovereign ratings are qualitative dependant variables but in the some of the literature the ratings are seen as quantiative dependant.

In this study we use the sovereign rating are ordered scales so we should use the ordered probit or logit models. A probability distribution function in the panel of multinominal models was given at equation belowed.

In this study we used the all countries variables between 2000 and 2017 the dependant variable for the first set of credit agencies which are Standart and Poors, Moodys and Fitch. We estimated random effect ordered probit models are presented in Table 2. The ordered model is more appropriate model to show the how the fundemantels effect the different sovereign credit ratings status or scales.

We identify the following detetminants of sovereign ratings with the external dept, inflation GDP per capita, GDP growth, real exchange rates, unemployement, current accaunt deficit they are found all statistically significant. The table 3 belowed,

Table 3. Results of Ordered Panel Probit (random effect model) model results for Standart \&Poors, Moody's and Fitch Agencies.

\begin{tabular}{llll}
\hline & $\begin{array}{l}\text { Standart\&Poors } \\
\text { (S\&P) }\end{array}$ & Moody's & Fitch \\
\hline Explanotary Variables & Coefficient & Coefficient & Coefficient \\
GDP per capita & 0.00142185 & 0.0006156 & 0.0166224 \\
(GPPP) & $(0.0277423)^{*}$ & $(0.0001231)^{*}$ & $(0.0023356)^{*}$ \\
Real Exchange Rates & -0.01505645 & -0.0145339 & -0.03991201 \\
(REXR) & $(0.0488626)^{*}$ & $(0.00214529)^{*}$ & $(0.0021786)^{*}$ \\
Inflation (CPI) & -3.2682331 & -0.3567824 & -0.16987645 \\
& $(0.5299763)^{*}$ & $(0.00318960)^{*}$ & $(0.00215634)^{*}$ \\
Unemployement & -0.156785 & -0.178122 & -0.817221 \\
(UNE) & $(0.0158875)^{*}$ & $(0.0012992)^{*}$ & $(0.0021288)^{*}$ \\
ExternalDept (ED) & -0.326552 & -0.001255 & -0.0159923 \\
& $(0.0702213)^{*}$ & $(0.000102)^{*}$ & $(0.0023120)^{*}$ \\
GDP Growth (GDPG) & -0.067559 & -0.069771 & -0.0723312 \\
& $(0.0005633)^{*}$ & $(0.0022124) *$ & $(0.002166)^{*}$ \\
CAD (Current & -0.03477 & -0.09052 & -0.527330 \\
Account deficit) & $(0.0022745)^{*}$ & $(0.002399)^{*}$ & $(0.003880)^{*}$ \\
Totalpanel & 102 & 102 & 102 \\
observation & 16 & 16 & 16 \\
Observations & 17 & 17 & 17 \\
Cross Sections & 17 & & \\
\hline & & & \\
\hline
\end{tabular}

\begin{tabular}{llll}
\hline & $\begin{array}{l}\text { Standart\&Poors } \\
\text { (S\&P) }\end{array}$ & Moody's & Fitch \\
\hline Log Likelihood & -188.06733 & -179.33078 & -193.11896 \\
S i g m a 2_u & 1.228966 & 2.132212 & 1.229821 \\
& $(0.0262977)^{*}$ & $(0.782399)^{*}$ & $(0.001233)^{*}$ \\
Cut $1^{* *}$ & 4.56748 & 3.221877 & 2.11342 \\
& $(0.227844)^{*}$ & $(0.001288)^{*}$ & $(0.1288327)^{*}$ \\
Cut $1^{* *}$ & 1.224533 & 2.132212 & 3.98453 \\
& $(0.894509)^{*}$ & $(0.0125673)^{*}$ & $(0.3356218)^{*}$ \\
Cut2 & 5.664409 & 3.124533 & 3.223116 \\
& $(0.332896)^{*}$ & $(0.128867)^{*}$ & $(0.243488)^{*}$ \\
Cut 3 & 4.891209 & 4.239908 & 4.2231764 \\
& $(0.332894)^{*}$ & $(0.331221)^{*}$ & $(0.003367)^{*}$ \\
Cut4 & 2.339055 & 2.346653 & 2.4438867 \\
& $(0.3321780)^{*}$ & $(0.324567)^{*}$ & $(0.228943)^{*}$ \\
Cut 5 & 3.1244532 & 3.220967 & 3.4533764 \\
Pseudo- $R_{2}$ & $(0.2298221)^{*}$ & $(0.1255646)^{*}$ & $(0.0412284)^{*}$ \\
\hline
\end{tabular}

*The Standart Deviation statistics in the parentheses the significance level at $\% 5$. **The cut levels shows the dependant variable has 6 categories (scales). ***Sigma_u shows the components of the variance. Wald tets statistic's prob is statistically significant that means the reject the null hypothesis all coefficient equal to zero.

Table 3 showes the all explanotary variables effect on the sovereign rates. For all coefficients are statistically significant so we can explain the negatif and positive effect on the sovereign rates. GDP per capita having positive effect on the rates for all agencies because the coefficient positive $(0,0014218)$ effect on the sovereign rates.

Inflation for having negative number $(-3.2621)$ for the standart poors and anothers. Unemployement is effect the sovereign rates negatively $(-0,017822)$ for the Moody's sovereign ratings. Real Exchange rates effect negatively (0.03991201) for the Fitch credit levels. The other coefficients are also having negative effect too for other agencies.

Table 3 shows the log likelihood levels the most explainable model for the Fitch (188.66) and the cut points of the panel probit model for each credit agencies are statistically significant and including all emerging countries.

In the Table 3 panel probit model the explanatory variables affect the independent variables positively or negatively. The effect of the dependent variable percentage on the sovereign scales for emerging market countries we estimated marjinal effects and we showed the ratio levels with each cutpoints.

In Table 3 every each sovereign rates probability with marjinal effects for all explonatory variables coefficients. We showed the cut points as a ratings level. This levels are calculated for the probability of the each credit scores how the explanotary variables will change these scores.

Table 4. Panel Ordered Probit random effect model) Marjinal Effects Results Each Rating Scale for Standart\&Poors (Marjinal Effects dy/dx).

\begin{tabular}{llllll}
\hline \multirow{2}{*}{$\begin{array}{l}\text { Explonatory } \\
\text { Variables }\end{array}$} & \multicolumn{2}{l}{ Coefficients } \\
\cline { 2 - 6 } Cut 1 & Cut2 & Cut3 & Cut4 & Cut5 \\
\hline GDP per capita & -0.0030 & -0.23882 & 0.0083 & -0.0022 & 0.0012 \\
(GPPP) & $(2.67)^{*}$ & $(2.78)^{*}$ & $(3.27)^{*}$ & $(3.66)^{*}$ & $(2.53)^{*}$ \\
Real Exchange & -0.001 & -0.0322 & -0.0775 & -0.0830 & 0.0149 \\
Rates(REXR) & $(2.03)^{*}$ & $(3.55)^{*}$ & $(4.10)^{*}$ & $(3.68)^{*}$ & $(2.55)^{*}$ \\
Inflation (CPI) & -0.0254 & -0.5187 & -0.4189 & -0.4683 & -5.3312 \\
& $(2.66)^{*}$ & $(2.05)^{*}$ & $(2.77)^{*}$ & $(3.12)^{*}$ & $(3.10)^{*}$ \\
\hline
\end{tabular}




\begin{tabular}{llllll}
\hline $\begin{array}{l}\text { Explonatory } \\
\text { Variables }\end{array}$ & \multicolumn{2}{l}{ Coefficients } \\
\cline { 2 - 7 } Cut 1 & Cut2 & Cut3 & Cut4 & Cut5 \\
\hline Unemployement & -0.2771 & 0.0123 & 0.0013 & 0.0013 & 0.04342 \\
(UNE) & $(-2.11)^{*}$ & $(-3.22)^{*}$ & $(-2.44)^{*}$ & $(-3.11)^{*}$ & $(-2.56)^{*}$ \\
External Dept & -0.0013 & -0.2122 & 0.2122 & 0.2015 & 0.1833 \\
(ED) & $(2.19)^{*}$ & $(3.22)^{*}$ & $(2.45)^{*}$ & $(4.55)^{*}$ & $(3.77)^{*}$ \\
GDP Growth & 0.0016 & 0.0004 & 0.0024 & -0.0033 & -0.0070 \\
(GDPG) & $(-2.58)^{*}$ & $(-2.45)^{*}$ & $(-1.98)^{*}$ & $(-2.16)^{*}$ & $(-2.79)^{*}$ \\
CAD (Current & 0.0010 & 0.0020 & 0.0018 & -0.0080 & 0.0076 \\
Account Deficit) & $(2.34)^{*}$ & $(2.56)^{*}$ & $(3.11)^{*}$ & $(3.44)^{*}$ & $(2.86)^{*}$ \\
CAD(Current & & & & & \\
account deficit) & & & & & \\
Pseudo-R2 & 0.433 & 0.458 & 0.322 & 0.215 & 0.387 \\
\hline
\end{tabular}

$\mathrm{z}$ statistics in parentheses $* \mathrm{p}<0.05$

In the table 4 we estimated the marjinal effects of probit models. The models shows the levels and the GDPper coefficient $(-0.0030)$ shows the one unit percent changement will decrease the high risk obligation (cut 1 ) probability for Standart\&Poors. The coefficient ratio (0.0012) shows the \%1 increasing on the GDP per capita will increase the ratio 0.0012 probability of having high quality (cut 3) for emerging countries.

For example the the probability of having high quality (cut 5) for emerging countries at the ratio of -5.3312 when Inflation increases $\% 1$ for Standart\&Poors egency. Table 5 shows the marjinal effects of for having probability of sovereign rates for Moody's.

Table 5. Panel Ordered Probit (random effect model) Marjinal Effects Results Each Rating Scale for Moody's (Marjinal Effects dy/dx).

\begin{tabular}{|c|c|c|c|c|c|}
\hline \multirow{2}{*}{$\begin{array}{l}\text { Explonatory } \\
\text { Variables }\end{array}$} & \multicolumn{5}{|c|}{ Coefficients } \\
\hline & Cut 1 & Cut2 & Cut3 & Cut4 & Cut5 \\
\hline GDP per capita & 0.0050 & 0.0034 & -0.0326 & -0.0422 & 0.0088 \\
\hline (GPPP) & $(2.29)$ & $(3.10)$ & $(2.25)$ & $(2.67)$ & $(2.03)$ \\
\hline Real Exchange & 0.0078 & 0.0010 & -0.0089 & -0.0867 & 0.0034 \\
\hline Rates (REXR) & $(1.98)$ & $(2.34)$ & $(2.45)$ & $(2.66)$ & $(2.19)$ \\
\hline Inflation (CPI) & $\begin{array}{l}-0.0014 \\
(2.11)\end{array}$ & $\begin{array}{l}-0.5551 \\
(-2.56)\end{array}$ & $\begin{array}{l}-0.5107 \\
(3.12)\end{array}$ & $\begin{array}{l}-0.6551 \\
(2.55)\end{array}$ & $\begin{array}{l}-0.3228 \\
(3.10)\end{array}$ \\
\hline $\begin{array}{l}\text { Unemployement } \\
\text { (UNE) }\end{array}$ & $\begin{array}{l}-0.0157 \\
(2.55)\end{array}$ & $\begin{array}{l}-0.0155 \\
(2.45)\end{array}$ & $\begin{array}{l}-0.0188 \\
(2.35)\end{array}$ & $\begin{array}{l}-0.0817 \\
(2.08)\end{array}$ & $\begin{array}{l}-0.0655 \\
(2.33)\end{array}$ \\
\hline ExternalDept (ED) & $\begin{array}{l}-0.1033 \\
(-2.88)\end{array}$ & $\begin{array}{l}0.0060 \\
(-2.17)\end{array}$ & $\begin{array}{l}0.1055 \\
(-2.45)\end{array}$ & $\begin{array}{l}0.0020 \\
(-3.19)\end{array}$ & $\begin{array}{l}0.0450 \\
(-3.03)\end{array}$ \\
\hline $\begin{array}{l}\text { GDP Growth } \\
\text { (GDPG) }\end{array}$ & $\begin{array}{l}-0.0122 \\
(2.44)\end{array}$ & $\begin{array}{l}-0.0444 \\
(2.56)\end{array}$ & $\begin{array}{l}-0.0155 \\
(2.87)\end{array}$ & $\begin{array}{l}-0.08378 \\
(2.66)\end{array}$ & $\begin{array}{l}-0.0636 \\
(2.87)\end{array}$ \\
\hline CAD (Current & -0.0344 & -0.0331 & -0.4544 & 0.4812 & -0.5412 \\
\hline Account Deficit) & $(2.18)$ & $(2.45)$ & $(2.55)$ & $(2.56)$ & $(2.66)$ \\
\hline Pseudo-R2 & 0.331 & 0.437 & 0.458 & 0.329 & 0.488 \\
\hline
\end{tabular}

$\mathrm{z}$ statistics in parentheses $* \mathrm{p}<0.05$

For example the probability of speculative grade ratings likely to fulfill obligation (cut 2) for emerging countries increases at the ratio of 0,0060 when the External Dept increases $\% 1$. When the high risk obligation probability will decrease the ratio of 0.0122 the Gdp growth increases $\% 1$ for Moody's. The adaquate payment capacity (cut 3) will increase the ratio of 0.1055 the External dept will increase $\% 1$.

Table 6 shows the estimated panel probit marjinal effects for Fitch credit scoring probabilities for selected emerging countries. When we look at the probability of strong payment capacity will decrease at the ratio 0.0015 when the GDP per capita increases $\% 1$ for Fitch having scoring.

Table 6. Panel Ordered Probit Marjinal Effects Results Each Rating Scale for Fitch(Marjinal Effects dy/dx).

\begin{tabular}{|c|c|c|c|c|c|}
\hline \multirow{2}{*}{$\begin{array}{l}\text { Explonatory } \\
\text { Variables }\end{array}$} & \multicolumn{5}{|c|}{ Coefficients } \\
\hline & Cut 1 & Cut2 & Cut3 & Cut4 & Cut5 \\
\hline GDP per capita & -0.0050 & -0.0015 & -0.0013 & -0.0190 & -0.0245 \\
\hline (GPPP) & (2.67) & $(2.55)$ & $(2.66)$ & $(2.78)$ & $(3.18)$ \\
\hline RealExchange & -0.0013 & 0.0017 & 0.0023 & -0.0012 & -0.0828 \\
\hline Rates (REXR) & $(3.12)$ & $(3.44)$ & $(2.55)$ & $(2.56)$ & $(2.05)$ \\
\hline Inflat & $\begin{array}{l}-0.0012 \\
(2.66)\end{array}$ & $\begin{array}{l}-0.0218 \\
(2.44)\end{array}$ & $\begin{array}{l}0.01677 \\
(2.57)\end{array}$ & $\begin{array}{l}0.0123 \\
(2.18)\end{array}$ & $\begin{array}{l}0.0189 \\
(2.32)\end{array}$ \\
\hline $\begin{array}{l}\text { Unemployement } \\
\text { (UNE) }\end{array}$ & $\begin{array}{l}0.0080 \\
(1.89)\end{array}$ & $\begin{array}{l}0.04355 \\
(-2.44)\end{array}$ & $\begin{array}{l}0.2689 \\
(-2.72)\end{array}$ & $\begin{array}{l}0.6778 \\
(-2.33)\end{array}$ & $\begin{array}{l}0.5577 \\
(-2.44)\end{array}$ \\
\hline External Dept & 0.0010 & 0.0020 & 0.0335 & 0.0221 & 0.0321 \\
\hline (ED) & (3.11) & (3.08) & (2.77) & $(2.84)$ & $(2.55)$ \\
\hline $\begin{array}{l}\text { GDP Growth } \\
\text { (GDPG) }\end{array}$ & $\begin{array}{l}-0.0030 \\
(-2.44)\end{array}$ & $\begin{array}{l}0.0023 \\
(-2.67)\end{array}$ & $\begin{array}{l}0.0712 \\
(-2.44)\end{array}$ & $\begin{array}{l}0.0526 \\
(-2.71)\end{array}$ & $\begin{array}{l}0.3913 \\
(-2.49)\end{array}$ \\
\hline $\begin{array}{l}\text { CAD (current } \\
\text { account deficit) }\end{array}$ & $\begin{array}{l}-0.012 \\
(2.56)\end{array}$ & $\begin{array}{l}-0.0133 \\
(2.31)\end{array}$ & $\begin{array}{l}-0.1455 \\
(2.45)\end{array}$ & $\begin{array}{l}-0.2233 \\
(2.55)\end{array}$ & $\begin{array}{l}-0.2755 \\
(3.12)\end{array}$ \\
\hline Pseudo-R2 & 0.360 & 0.430 & 0.380 & 0.452 & 0.366 \\
\hline
\end{tabular}

$\mathrm{z}$ statistics in parentheses $* \mathrm{p}<0.05$

The probability of highest quality for emerging countries will increase the raito of 0.0080 when the unemployement increases $\% 1$. The probability of highest quality will decrease the ratio of 0.0030 when the GDP growth inceases \%1. The probability of high quality for emerging countries increases at the ratio of 0,0189 when the unemployement increases $\% 1$ and the ratio of 0.5557 when the inflation increases $\% 1$. The probability of the high risk obligation will decrease the ratio of 0.012 when the current account deficit increases $\% 1$.

\section{Conclusion}

This study investigated the many economic and social factors impact on the sovereign credit rating probabilities for emerging countries. We used the ordered panel probit analysis to identify the sovereign credit rating determinants. We used the emerging countries data the sample covered 2000-2017 and rating from the three big rating agencies named Standart\&Poors, Moody's and Fitch.

In this study we used the economical indicators GDP per capita, unemloyement, real exchange rates, inflation, current account deficit, external dept, GDP growth. We estimated the all variables statistically significant for all agencies. We found some effects on the sovereign ratings with panel probit model for all agencies. The results shows that negative effect of external dept, inflation, current account deficit, gdp growth and unemployement but positive effect of GDP per capita on the soverign ratings. Marjinal effects results give the different levels when the seperate the credit rating levels. We estimated the all credit score level probabilities and for each agencies and we saw that the determinants of the sovereign rates changement all the scoring leves that we calculated with panel ordered probit model.

We used the macroeconomic indicators and all the credit score probabilites estimated with the marjinal effects of the 
panel ordered probit model. This study can be extanded finding the default and nondefault probabilities with other models. For his purpose our model is suitable to find the scoring probabilites and the impact of the determinants of sovereign credit scoring.

\section{Compliance with Ethical Standards}

\section{Funding}

This study has no foundation.

\section{Conflict of Interest}

All the authors do not have any possible conflicts of interest.

\section{(In Case Animals Were Involved) Ethical Approval}

All applicable international, national, and/or institutional guidelines for the care and use of animals were followed. (In this study there is nothing about animals caring and using).

\section{Ethical Approval}

This article does not contain any studies with human participants or animals performed by any of the authors.

\section{References}

[1] Afonso, A. (2003) Understanding the Determinants of SovereignnDept Ratings: Evidence for the Two Leading Agencies. Journal of Economics and Finance, vol. 27 (1), pp. $56-74$

[2] Afonso A., Gomes P., Rother P. (2011). Short-and Lon Run Determinants of Sovereign Dept Credit Ratings. International Journal of Finance\&Economics, vol. 16(1), pp. 1-15.

[3] B. H. (2008). Econometrics Analysis of Panel Data. West Sussex: Wiley Bissondoyal Bheenick E., Brooks R., Yip A. Y. N. (2006). Determinants of Sovereign Ratings: A Comparison of Case -Based Reasoning and Ordered Probit Approaches. Global Finance Journal, vol. 35(3), pp. 53-73.

[4] Butler A. W., Fauver, L. (2006), Institutional environment and sovereign credit rating. Financial Management, 35 (3), 53-79.

[5] Brooks C. (2008). Introductory Econometrics for Finance (2nd ed.). New York: Cambridge University Press.

[6] Cantor R., Packer F. (1996). Determinants and Impact of Sovereign Credit Ratings, FRBNY Economic Policy Rewiev October, October, 37-54 Constantin Mellios and Eric PagetBlanc WHICH FACTORS DETERMINE SOVEREIGN CREDIT RATINGS?, p, 1-3.

[7] Depken C. A., La Fountain C., Butters R. (2006). Corruption and Creditworthiness: Evidence from Sovereign Credit Ratings. University of Texas at Arlington, Department of Economics Working Papers, vol. 0601.

[8] Eliasson, A. (2002), "Sovereign Credit Ratings", Working Papers 02-1, Deutsche Bank.

[9] Ferri G. (2004). More Analysts, Better Ratings: Do Rating Agencies Invest Enaugh in Less Developed Countries? Journal of Policy Modelling, 133-156.

[10] Guris, S (2015), Stata ile Panel veri Modelleri, Der Yayınları, p. $190-192$.

[11] Jaramillo L. (2010), "Determinants of Invesment Grade status in Emerging Markets" IMF Working Paper 10/117.

[12] Jaramillo L., C. M. Tejada, 2011, Sovereign Credit Ratings and Spread in Emerging Markets: Does Investment Grade Matter?, IMF Working Paper, p:11-44.

[13] Hu Y. T., Kiesel R., Perraudin W. (2002). The estimation of Transition Matrices for Sovereign Credit Ratings. Journal of Banking \&Finance, vol. 26(7), pp. 1383-406.

[14] Long J. S., Freese J. (2006). Regression Models for Categorical Dependent Variables Using Stata. Texas: Stata Press.

[15] Marinda P, I Botha, (2014). 'A Panel Ordered Response Model for Severeign Credit ratings in Africa, Economic Research Southern Africa september 26, ERSA working paper 464.

[16] Martin A, Marek K, (2015). 'Sovereign Credit Rating in Ordered Response Model Framework- Case of Visegred Four Countries '. European Financial Systems 2014, Proceedings of the 11th International Scientific Conference, Brno: Masaryk University, 2014, pp. 11-17. ISBN 978-80-210-7153-7.

[17] Mellios, C., Paget-Blanc, E. (2006), "Which Factors Determine Sovereign Credit Ratings", The European Journal of Finance, Vol. 12, No. 4, pp. 361-377.

[18] Mora N. (2006). Sovereign Credit Ratings: Guilty Beyond Reasonable Doubt? Journal of Banking \& Finance, vol. 30(7), pp. 2041-62.

[19] Mulder C., Perrelli R. (2001, November). Foreign Currency Credit ratings for Emerging Market Economies. IMF working paper.

[20] Rowland, P., Torres, J. (2004), "Determinants of Spread, Credit Ratings and Creditworthinessfor Emerging Market Sovereign Debt: A Panel Data Study", Borradores de Economia, No. 295, Banco de la República de Colombia.

[21] Standart and Poor's. (2014). Understanding ratings. Retrived August 6, 2014, from McGrawHill Financia: http://www.spratings.com http://www.nkc.co.za

[22] http://www.wordlbank.data

[23] http://www.imf.org/external/pubs/ft/wp/2010/data/wp10245.zip 